\title{
The global financial crisis and the shift to shadow banking
}

\author{
Yeva Nersisyan* and L. Randall Wray*
}

\begin{abstract}
While most economists agree that the world is facing the worst economic crisis since the Great Depression, there is little agreement as to what caused it. Some have argued that the financial instability we are witnessing is due to irrational exuberance of market participants, fraud, greed, too much regulation, etc. However, some post-Keynesian economists following Minsky have argued that this is a systemic problem, a result of internal market processes that allowed fragility to build over time. In this paper we focus on the shift to the shadow banking system a and the creation of what Minsky called the Money Manager phase of capitalism. In this system, rapid growth of leverage and financial layering allows the financial sector to claim an ever rising proportion of national income - what is sometimes called 'financialization - as the financial system evolved from hedge to speculative and finally to a Ponzi scheme.

The policy response to the financial crisis in the US and elsewhere has largely been an attempt to rescue money manager capitalism. Moreover, in the case of the US the bailout policy has contributed to further concentration of the financial sector, increasing dangers. We believe that the policies directed at saving the system are doomed to fail-and that alternative policies should be adopted. The effective solution should come in the way of downsizing the financial sector by two-thirds or more, and effecting fundamental modifications.

JEL classifications: $G 2 I, G 23, G 28$

Keywords: Institutional Investors; Financial Crisis; Financialization; Money Managers; Financial Concentration; Shadow Banking; Subprime Mortgages; Securitized Mortgages
\end{abstract}

* University of Missouri-Kansas City, USA.

Correspondence Address:

Yeva Nersisyan / Randall Wray, Haag Hall 2II, Economics Department, University of Missouri-Kansas city, 5IOo Rockhill Road, Kansas city, MO 64IIo, USA, e-mail: ysnz72@mail.umkc.edu / wrayr@umkc.edu.

Received o3 February 20I0, accepted o6 July 2010

C INTERVENTION 7 (2), 20I0, 377-400 


\section{Introduction}

There is little doubt that the current crisis is the worst since the Great Depression. Proffered explanations regarding the causes include: irrational exuberance, perverse incentives, greedy bankers, and misguided policy. Some economists who follow Minsky, however, have argued that the current crisis resulted from the fundamental flaws of capitalism, and particularly of what Minsky called money manager capitalism (Wray 2009). It was not unexpected, and came as a shock economists of the Chicago persuasion. As Minsky warned, stability is destabilizing and it is not surprising that in the context of deregulation and de-supervision starting in 1970 s the financial system had become prone to repetitive crises that became more frequent, severe, and longer-lasting.

This paper sheds light on the changes that have occurred in the US financial system over the post war period as it came to take an ever larger share of income flows. Similar transformations have taken place in the global financial system, but here we will focus on the US. An examination of the shift of the relative weights of various types of financial institutions as well as other developments in the financial sector shows how the whole system evolved toward fragility. Increased concentration in the banking sector has created a few large stoo big to fail institutions said to be of systemic importance - institutions we would prefer to designate as stoo big to saver because they are systemically dangerous،. This problem is exacerbated after each crisis as institutions that survive the crisis become bigger and more powerful.

Meanwhile, even though large portions of managed money have been wiped out during the crisis, it is obvious that it has made a comeback and is looking for another bubble. And policy is actually pursuing a strategy of increasing the size and importance of the most dangerous institutions. The response in Washington has been to save these dangerous institutions and then to propose creation of a ssystemic regulator. We believe the mega-institutions are too complex and too politically powerful to effectively regulate. Hence, we propose downsizing institutions as well as the financial system as a whole. Despite its recent anti-Wall Street rhetoric, the Obama administration has failed to bring any significant changes to the way finance operates. Even Obama's timid proposals, such as taxing banks that received bail-out money, are facing major resistance from the financiers, thus, are unlikely to pass. As memories of the crisis fade away, the momentum for real change has been lost. Indeed, the policy response to date has sown the seeds for another crisis. We do not have the space to delineate specific alternatives, but argue that downsizing finance is a prerequisite to achieving any success at restoring stability to the financial system.

\section{Financialization of the US economy}

Minsky adopted a stages approach to the evolution of the financial system, calling the current phase Money Manager Capitalism, characterized by »highly levered profit-seeking or- 
ganizations « such as money market mutual funds, mutual funds, sovereign wealth funds, and private pension funds (Minsky 1986/2008: 274). A number of structural changes have contributed to creating a fragile financial system. The ultimate outcome is repetitive bubbles, which turn into financial crises after blowing up. With government bail-outs to save financial institutions, after each crisis the financial sector >recovers` first, leaving long lasting impacts on the real economy in terms of lost output and prolonged unemployment and setting the stage for the next collapse. While the typical recession since the early I970s has been relatively shallow, recovery has taken a long time as job creation is slow to resume.

Minsky rightly argued that relatively robust performance of the economy immediately after the post-war period was not due to the private sector becoming more stable, rather, it was the outcome of effective institutional constraints in the form of regulation, and creation of the Big Government and Big Bank. Another factor conducive to stability was that most debts had been wiped out during the depression leaving the private sector with little debt - simplifying balance sheets in Minsky's terms. Additionally, a large government deficit gave households and firms a safe financial asset in the form of government debt that was leveraged to produce robust growth (Wray 2009). Over time, the ratio of government debt to GDP fell, while the private debt ratios grew.

Meanwhile, the New Deal Reforms ensured the financial sector's share of the economy remained fairly limited: it only performed a supporting role for the productive sector. A number of rules helped to restrict concentration in the financial sector and forestalled the emergence of large institutions of 'systemic importance - especially the Glass-Steagall Act that separated commercial banks from investment banks ensuring a guaranteed profit for the former, as well as interstate banking rules that helped to limit the size of institutions and made regulating them easier. Thus, the immediate post war period experienced a long expansion with mild recessions but no financial crises. But stability is destabilizing, and this long period of robust growth created the necessary conditions for financial crises to return. Financial innovations circumventing regulation eroded New Deal regulations, and the system gradually transitioned to fragility making another debt deflation possible.

Over time, we saw an increasing role for the financial sector, the so-called financialization of the economy. Unlike the early postwar period where finance played a peripheral role, largely supporting the industrial sector, in most developed countries it now dictated the rules of the game. Krippner defines financialization as a "pattern of accumulation in which profits accrue primarily through financial channels rather than through trade and commodity production" (Krippner 2005: 174). Indeed, the distinction between ,financer and sindustry disappeared as major manufacturers such as General Electric and General Motors constructed financial arms that were (at times) far more profitable than their manufacturing business. This made the real economy vulnerable to the instability in the financial sector - since a financial crisis would threaten even manufacturers with bankruptcy.

Figure I shows how the financial sector's share of corporate profits rose rapidly (especially since the I970s) while its contribution to gross value added has remained relatively stable. In recent years, while the financial sector contributed just 20 per cent to GDP it reaped 40 per cent of corporate profits. 
Figure I: Share of the financial sector in corporate profits and value added

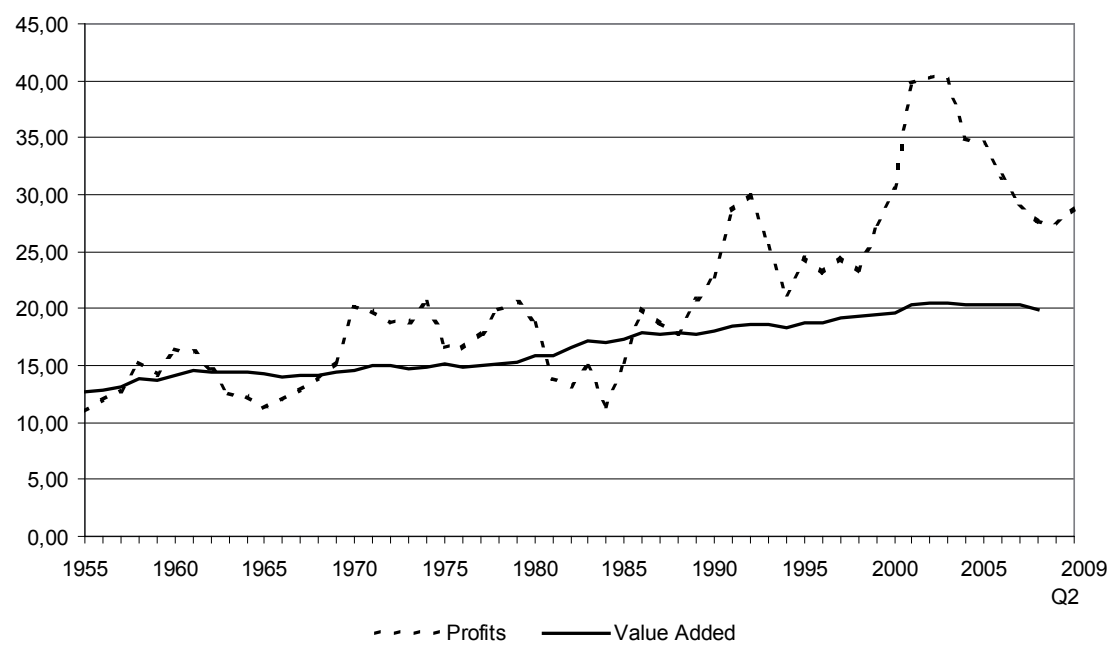

Source: BEA

Figure 2 depicts the financial sector's outstanding debt. From the mid I970s debt has been growing rapidly - much more rapidly than GDP or the income flows necessary to service the debt. This indicates that ^leverage or `layering for the whole system has increased. Without the Big Bank and Big Government the graph would look very different: during

Figure 2: Financial sector credit market dept outstanding (in \% of GDP)

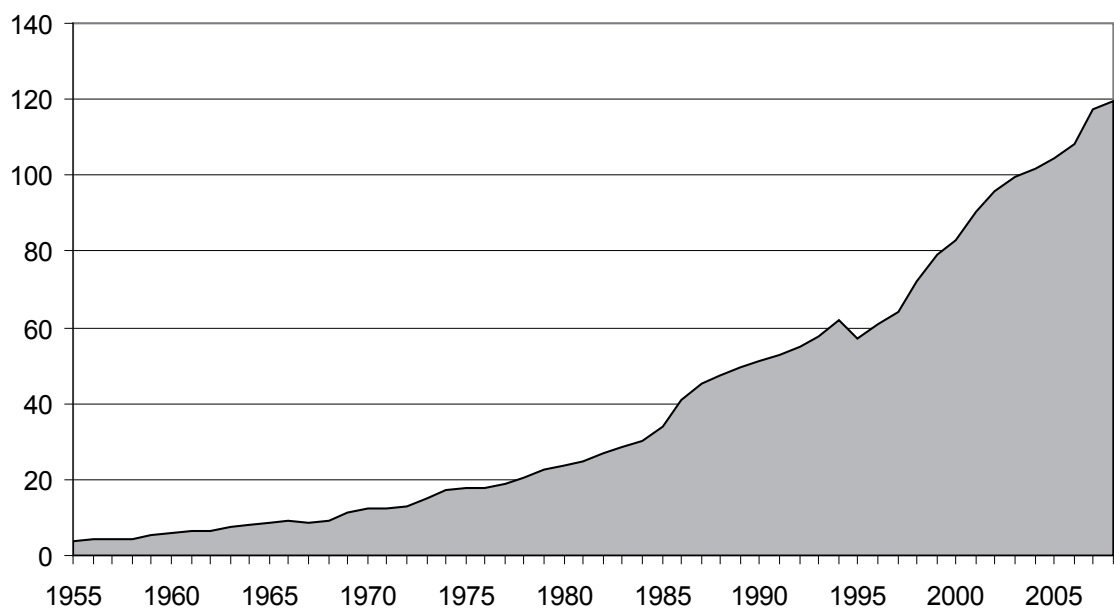

Source: Federal Reserve Flow of Funds Account 
each crisis the level of outstanding debt would decrease due to defaults. That was exactly what happened over the course of the I930s - so that the economy emerged from the depression with almost no private sector debt. But without a large-scale debt deflation, the financial sector has been allowed to expand outstanding debt to I2O per cent of US GDP. Hence, without a depression to wipe out debt, it continued to grow on trend. That is why the financial sector was able to capture an ever-rising share of profits. Not only did this hinder sreal production` as firms and households had to devote larger portions of income to debt service, but also it focused capitalist attention on the financial sector rather than the real sector because it appeared to be more profitable.

\section{I Concentration and shift to the shadow financial sector}

The regulatory framework's dismantling since the I970s boosted growing concentration in the financial system. US financial institutions grew in part because of the elimination of niche banking, allowing big banks to engage in a larger variety of financial activities. With globalization and the rise of securitization, many large domestic institutions became active participants in global financial markets thus growing even bigger. Each sector came to be dominated by a few large institutions with each institution being so large as to be able to bring down the whole system if it failed. By 2007 the top 4 banks accounted for over 40 per cent of bank assets.

Another major transformation was the shift of the weight of the financial system away from banks and toward `markets` or what Minsky called managed money. Commercial banks and savings institutions have become a much smaller share of the financial sector as seen from the relative shrinking of their assets. In 2007, institutional investors held about $\$ 24$ trillion, or 38 per cent of total financial assets of the financial sector, compared to \$I2 trillion, or I9 per cent, held by banks (Flow of Funds Accounts). The rise of money managers has been accompanied by concentration of assets in each sector in the hands of very few institutions.

Figure 4 shows financial sector total credit market debt outstanding. Credit market debt owed by commercial banks, finance companies and savings institutions has decreased while borrowing by issuers of ABS, Agency- and GSE-backed mortgage pools as well as funding corporations has grown. A remarkable change is the increase of credit market borrowing by ABS issuers: from nothing in 1984 to more than 20 per cent of total credit market borrowing in 2008. Issuers of ABS are Special Purpose Vehicles established to hold assets and issue debt obligations backed by those assets. These are not actual institutions but rather entities created for bookkeeping purposes (Guide to Flow of Funds Accounts). Banks set up ABS issuers to move securitized assets from their balance sheets to that of the former. These Special Purpose Vehicles then issue bonds and commercial paper which are backed by the assets in the pool. This allows regulated banks to avoid capital and reserve requirements - increasing leverage and return on equity. 
Figure 3: Shares of financial institutions (in \% of total assets)

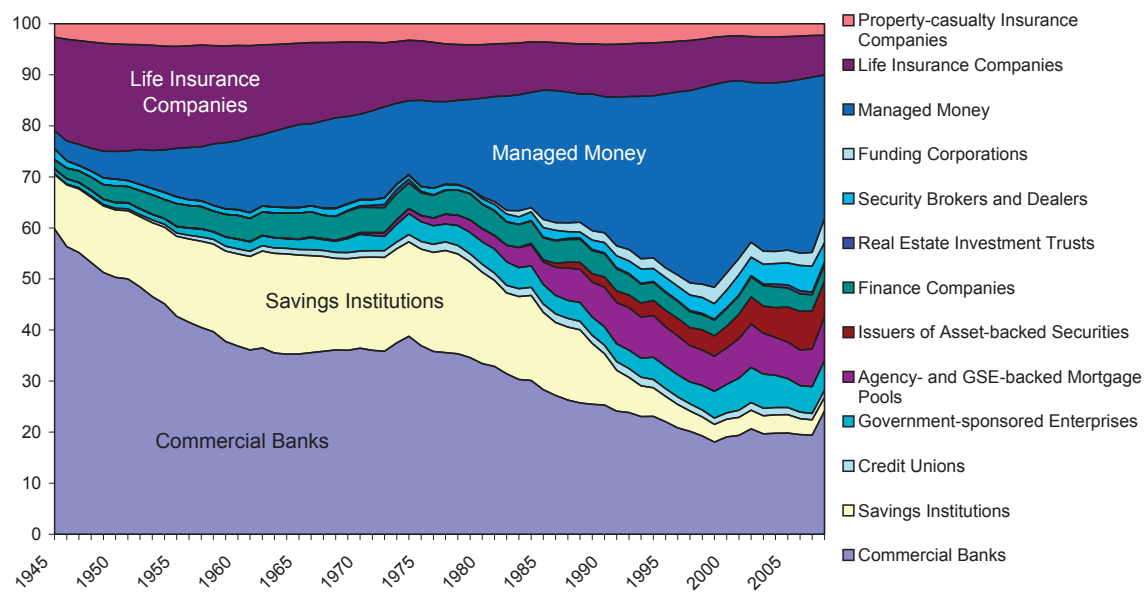

Source: Federal Reserve Flow of Funds Accounts

Figure 4: Credit market debt owed by financial institutions

(in \% of total owed by the financial sector)

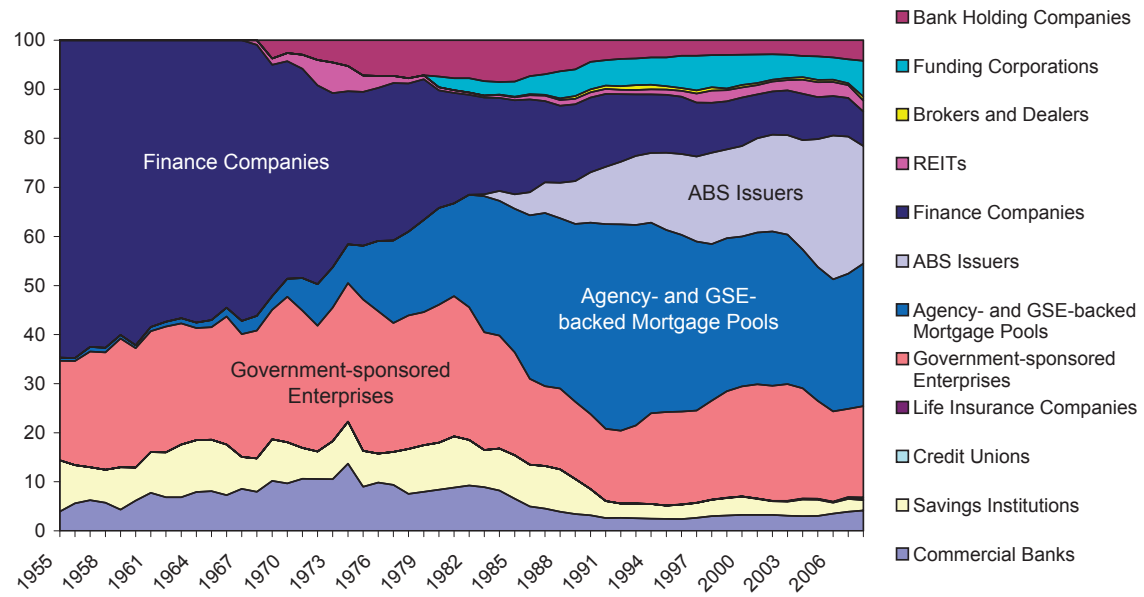

Source: Federal Reserve Flow of Funds Accounts 


\subsection{The banking sector}

Following his dissertation advisor, Schumpeter, Minsky argued that banks are central to the operation of a capitalist economy and that the assets and liabilities of banks largely determine the financial framework of the economy (Minsky 1986/2008: 354). The fragility of the financial structure is based on the quality of loans made by bankers. If bankers finance risky operations, they become fragile. Before the invention of securitization, banks were interested in granting loans only to creditworthy customers. As Minsky argued, a successful loan officer was considered to be "a partner of a borrower" (Minsky 1986/2008: 260 26I). Financial innovations such as securitization and Credit Default Swaps, however, have separated risk from responsibility, contributing to a deterioration of loan quality and hence greater fragility. Deregulation allowed banks to engage in all sorts of risky activities many of which are incompatible with the role banks are supposed to play. Many of the larger banks have changed so much that it is unclear whether they can be called banks - since they did little underwriting, and tried to shift risks off balance sheets - either by packaging and selling assets or by purchasing sinsurance in the form of CDSs.

As shown in Figure 5, the number of commercial banks has decreased by half to about 7,000 banks in the past two decades not counting the failure of many small banks that will come in the months ahead. This is remarkable considering that the number of institutions was almost constant at about I4,00o from 1934 to 1985 . Of course this reflected two trends: rising concentration but also the shift of importance to $>$ markets or what are called shadow banks.

Deregulation has contributed to increased banking concentration, largely due to the elimination of Glass-Steagall as well as the outcome of the stoo big to fail policy response during each crisis. Concentration has made the financial sector more fragile by creating a few large institutions that dominate more than half of the sector. The top I 8 banks currently hold about 60 per cent of total assets with the top 4 holding about 40 per cent (this is even higher than pre-crisis levels) - compared with only 23 per cent of total bank assets in I992 (see Figure 6 and 7). Further, as compared with I992, these are now ıuniversal banks‘, permitted to engage in a wide range of financial activities, from commercial banking to investment banking and to insurance.

The income statement and the balance sheets of commercial banks reveal the changes that these institutions have undergone. In particular, noninterest income has become a larger share of income - see Figure 8. Much of this comes from `off-balance sheet $>$ activities; according to Mishkin non-interest income from off-balance sheet activities of banks increased from 7 per cent of total income in 1980 to 44 per cent in 2007. (Mishkin 2007) Some of this comes in the form of fees, some from trading.

The largest US bank holding company is JPMorgan Chase. Unlike the smaller banks or banks as a whole, its non-interest income has exceeded interest income. The largest chunk of the non-interest income (about a quarter) comes from Trading Account gains and fees. The next biggest category is Net Securitization Income and Servicing Fees, averaging nearly is per cent of non-interest income from $2002-2009$. Investment banking, advisory, brokerage, and underwriting fees and commissions have averaged $\mathrm{s} 3$ per cent. Hence these three 
Figure 5: Number of banks I934-2008

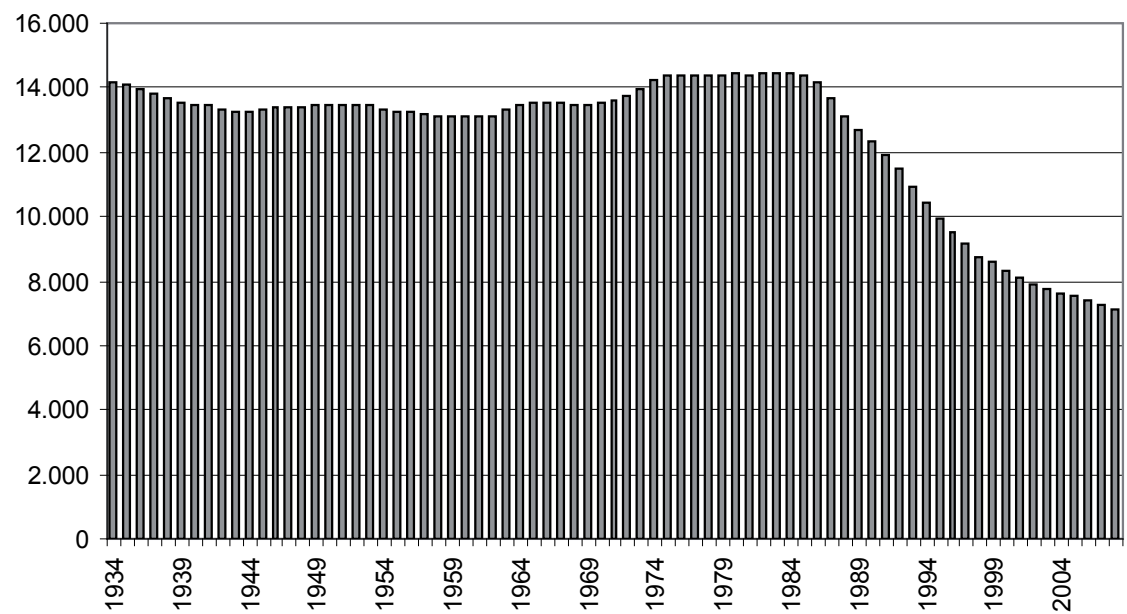

Source: Federal Deposit Insurance Corporation

Figure 6: Total assets and deposits held by top I8 banks (in \% of total)*

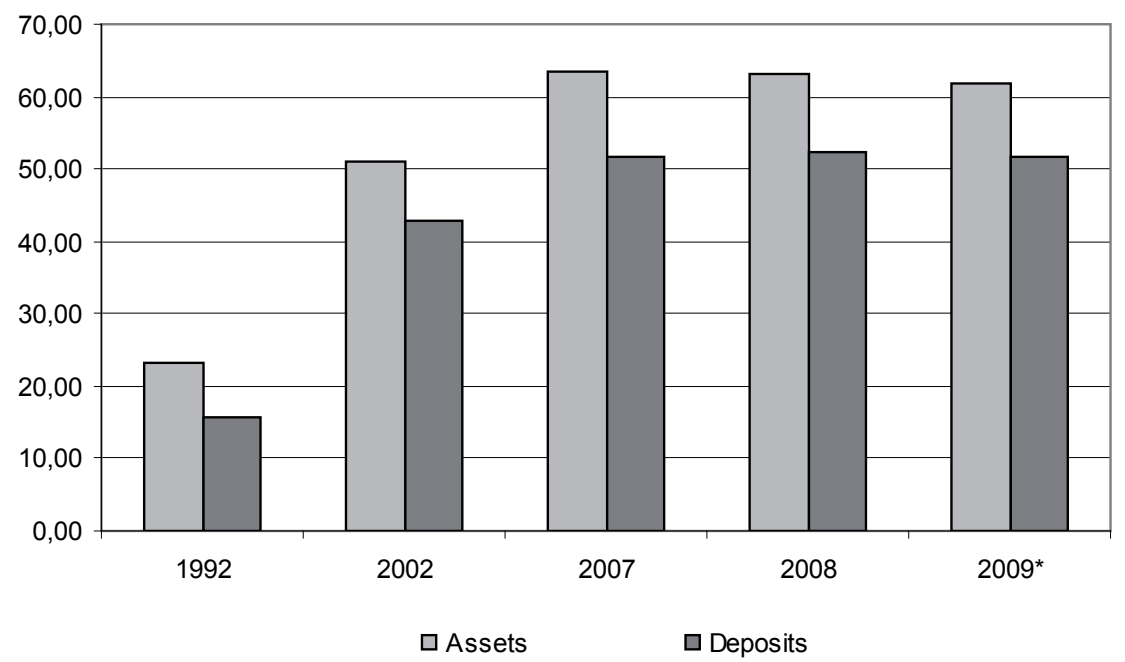

Note: * As of June 30, 2009.

Source: Federal Deposit Insurance Corporation 
Figure 7: Share of total bank assets: 4 largest banks

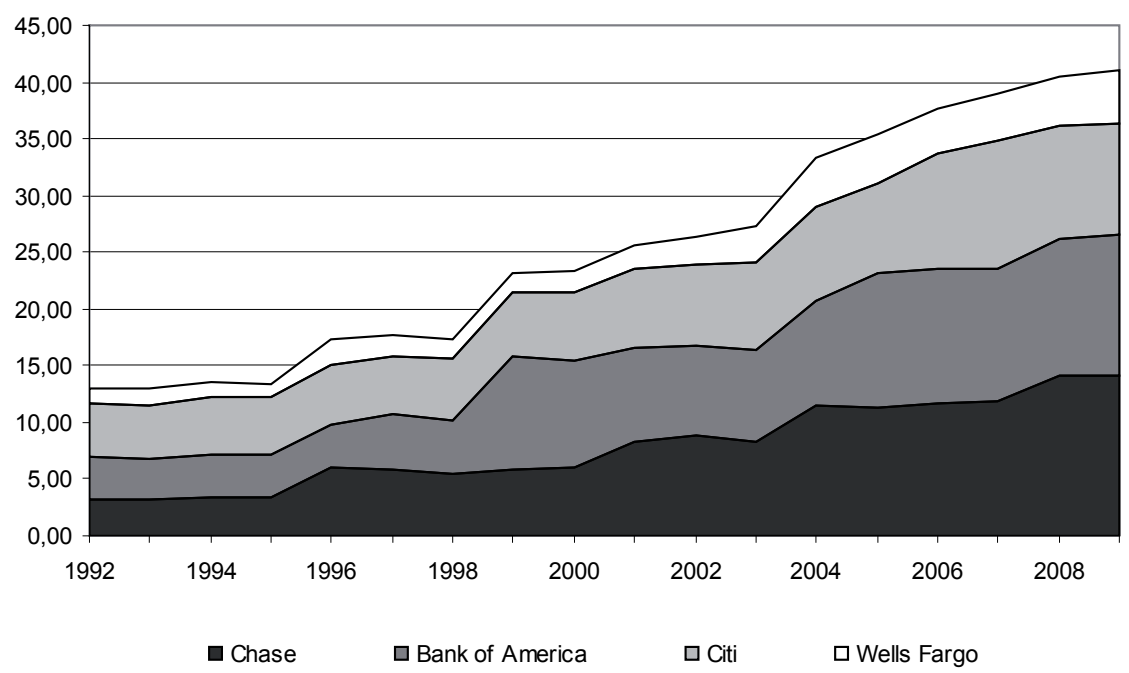

Source: Federal Reserve Flow of Funds Accounts

Figure 8: Interest vs. non-interest income of all FDIC insured banks (in billions US \$)

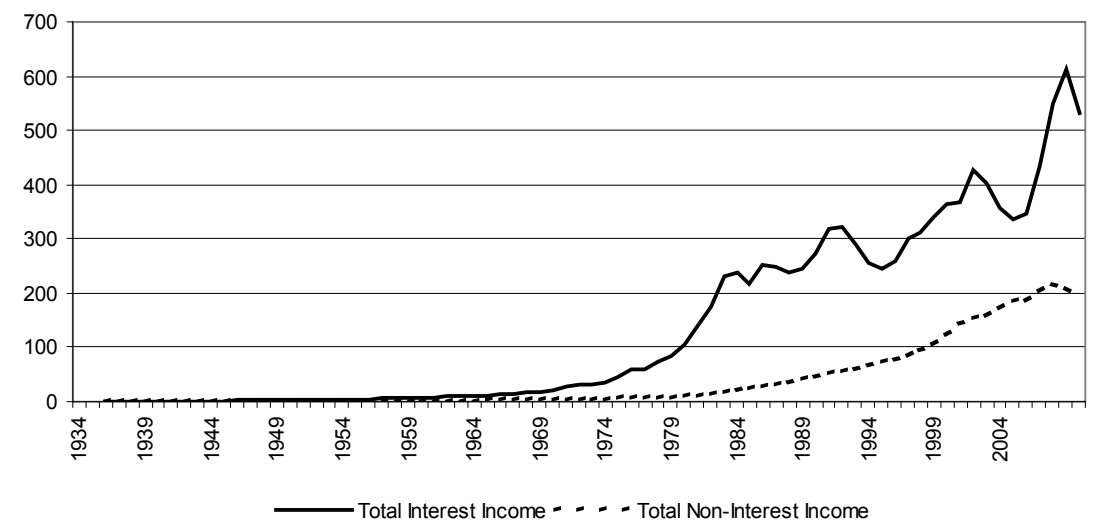

Source: Federal Deposit Insurance Corporation

categories together have been the source of more than 50 per cent of non-interest income. Indeed, at the peak of the boom, non-interest income was twice as big as net interest earnings as shown in Figure 9. 
Figure 9: Chase: Interest vs. non-interest income (in thousands US \$)

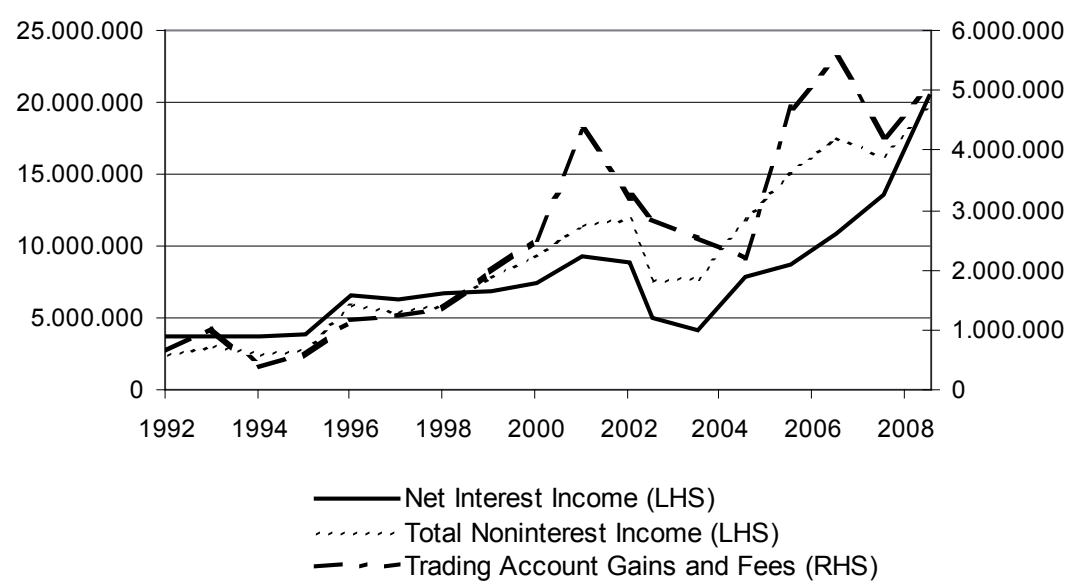

Source: Federal Deposit Insurance Corporation

As Minsky argued, if bankers put emphasis on the value of collateral rather than expected cash flows a fragile financial system emerges because loan viability depends on expected market value of the assets pledged (Minsky I986/2008: 26I). This is precisely what has happened: banks originated mortgages which largely depended on the value of the collateral and especially on the bubble to maintain rising prices. Commercial and Industrial loans have decreased from 20 per cent of total assets to Io per cent on average. This indicates that the larger banks aren't really in the business of making loans to businesses. Therefore, the major rationale for bailouts of the biggest banks - that capital injections into the larger banks will get credit flowing again to business - is fundamentally flawed. Help for small and medium sized banks might lead to more business loans, but the biggest banks are largely focused on other activities.

Table I.I: Top I8 banks (\% of assets)

\begin{tabular}{lcccc}
\hline & I992 & 2002 & 2007 & 2008 \\
\hline Net Loans and Leases & 59.58 & 54.26 & 56.40 & 47.50 \\
All real Estate Loans & $2 \mathrm{I} .39$ & 25.78 & 30.13 & 25.00 \\
Commercial Real Estate & 4.29 & 4.09 & 3.77 & $3.7 \mathrm{I}$ \\
I - 4 family residential & II.47 & I8.18 & $2 \mathrm{I} .89$ & I7.34 \\
Commercial and Industrial Loans & 20.67 & I3.II & II.80 & IO.9I \\
\hline
\end{tabular}

Source: Federal Deposit Insurance Corporation 
Table I.2: Top 3 banks (\% of assets)

\begin{tabular}{lrrrr}
\hline & I992 & 2002 & \multicolumn{1}{c}{2007} & \multicolumn{1}{c}{2008} \\
\hline Net Loans and Leases & 65.72 & 49.32 & 47.37 & 43.03 \\
All real Estate Loans & 23.73 & I7.16 & 22.46 & 22.73 \\
Commercial Real Estate & 3.53 & 2.00 & I.83 & I.9I \\
I - 4 family residential & I3.48 & I2.33 & I7.69 & I7.22 \\
Commercial and Industrial Loans & $2 \mathrm{I} .58$ & I3.84 & II.68 & IO.28 \\
\hline
\end{tabular}

Source: Federal Deposit Insurance Corporation

Table 1.3: All other banks (\% of assets)

\begin{tabular}{lrrrc}
\hline & \multicolumn{1}{c}{1992} & 2002 & 2007 & 2008 \\
\hline Net Loans and Leases & 55.46 & $6 \mathrm{I} . \mathrm{I} 7$ & 67.79 & 65.83 \\
All real Estate Loans & 25.79 & $32.8 \mathrm{I}$ & 40.85 & $4 \mathrm{I} .78$ \\
Commercial Real Estate & 8.28 & $\mathrm{II} .77$ & $\mathrm{I5} .35$ & $\mathrm{I} 4.66$ \\
I - 4 family residential & $\mathrm{I} 3.75$ & $\mathrm{I} 4.54$ & $\mathrm{I} 3.06$ & $\mathrm{I} 6.05$ \\
Commercial and Industrial Loans & $\mathrm{I} 3.67$ & $\mathrm{I} 2.62$ & $\mathrm{I} 4.2 \mathrm{I}$ & $\mathrm{I} 2.52$ \\
\hline
\end{tabular}

Source: Federal Deposit Insurance Corporation

Tables I.I - I.3 show the loan composition of banks. We have divided the banks into 3 groups: the largest 3 , the largest I 8 and all remaining banks. Larger banks are quite different from smaller banks in terms of the quantity as well as the type of loans. The largest 3 banks' loans and leases have decreased from 65 per cent of total assets to about 43 per cent in just over 15 years. Real estate loans have remained relatively stable at around 22 per cent, however, I -4 family residential loans (which were the main product for securitization) have risen. A very important change is the decrease in commercial and industrial loans - from about 22 per cent of total assets to II per cent in the last 15 years. The picture is fairly similar for the top I8 banks.

Commercial loans are granted with the expectation of future cash flows. Residential loans, on the other had, were increasingly made against the value of collateral. Reliance on residential mortgages made the banks vulnerable to changing conditions in the housing market thus giving rise to fragility.

Declining Net Loans and Leases has been accompanied by increasing trading. For example, at Chase trading has increased from 2.57 per cent of assets in 1992 to about 2I per cent of assets in 2008 and for BOA from 2.43 per cent of assets in 1992 to about II per cent in 2008. A decrease in loans has also been compensated by holding more securities (rising from 5 per cent to 17 per cent of assets), and particularly asset backed securities. At Citi- 
bank loans and leases have decreased to about 44 per cent from over 64 per cent of assets. Securities peaked at the end of 2006 at over 20 per cent of assets and trading account assets at over 17 per cent of assets in 2007. In sum, these data show that the larger banks are different from traditional banks: for the most part, lending to the productive sector is less important for them.

\subsection{Innovations}

Two innovations fragility: securitization and credit default swaps. The two developments go hand in hand with banks securitizing every type of loan and the CDS issuers rinsuring these securities. This was very important in promoting the belief that lack of underwriting was not important. Various kinds of insurance, including buy-back guarantees as well as CDSs made the securitized mortgages (and other types of loans) appear safe, thus, supported high prices for them. At the peak of the bubble mortgage backed securities were about 70 per cent of total securities of the large banks and about 50 per cent for smaller banks. Larger banks securitized from 40 to 60 per cent of I-4 family residential loans, selling securities to managed money. AIG and other sellers of CDS were eager to insures all these risks, enhancing credit.

CDSs are marketed as insurance, or a way to hedge against risks and therefore distribute it to market participants who are most willing and able to bear it. However, as Lewis (2009) nicely explains, CDSs create risk out of thin air, essentially allowing holders to make bets on the death of assets, firms or even national governments. CDS were initially used to safeguard investments in company bonds but with the increasing levels of securitization any type of debt came to be viewed as insurable by CDS. Wall Street banks also used CDS to mask the risks they had on their books. By engaging in risky activities and meantime shedging by buying CDS banks seemed to remain relatively risk free in the eyes of regulators. It could get pretty convoluted because CDSs allowed one to make bets on failures of assets, firms, or even nations. Goldman Sachs for example declared that it was immune to AIG's failure because it had hedged against that by buying CDS betting on AIG's failure (Lewis 2009). In other words, Goldman could hold risky securities, purchase insurancer from AIG on those securities, then make a bet that AIG would fail to honor that insurance - and thereby seemingly protect itself from any risk. But for any such bet, there is a counterparty that must make good - and that is eventually what brought the whole superstructure to crisis.

The data on derivatives is impressive. JPMorgan Chase, for example, held derivatives worth 6,072 per cent of its assets at the peak of the bubble in 2007. The other two giants, Citigroup and Bank of America, although still far behind Chase, had 2,022 per cent and 2,486 per cent respectively. Goldman Sachs, the other giant, had an astonishing amount of derivatives on its balance sheets: 25,284 per cent of assets in 2008 and 33,823 per cent as of June 2009. Citigroup and BOA now have more of this risk on their books than before the crisis (FDIC, SDI database). 
Table 2: Notional value of derivatives of 3 largest banks (\% of assets)

\begin{tabular}{lccccccccc}
\hline Year & 1992 & 1993 & 1994 & 1995 & 1996 & 1997 & 1998 & 1999 & 2000 \\
\hline BOA & 29 & 149 & 331 & 568 & 771 & 622 & 744 & 975 & 1,214 \\
Citi & - & - & - & - & - & - & 1,017 & 930 & 1,064 \\
Chase & - & - & - & - & 1,769 & 2,180 & 2,905 & 3,240 & 4,004 \\
\hline Year & 2001 & 2002 & 2003 & 2004 & 2005 & 2006 & 2007 & 2008 & $2009^{*}$ \\
\hline BOA & 1,588 & 2,062 & 2,227 & 1,655 & 1,864 & 1,950 & 2,022 & 2,111 & 2,221 \\
Citi & 1,083 & 1,235 & 1,421 & 1,841 & 2,177 & 2,286 & 2,486 & 2,399 & 2,527 \\
Chase & 3,992 & 4,363 & 5,529 & 4,236 & 4,425 & 5,186 & 6,072 & 4,744 & 4,562 \\
\hline
\end{tabular}

Note: * June 30, 2009

Source: Federal Deposit Insurance Corporation, SDI database

The largest chunk of these derivatives is interest rate swaps. It is still unknown how large the CDS market is as the derivatives market is mostly unregulated. Figures IO.I - IO.4 depict the level of Credit Derivatives (the notional amounts). FDIC doesn't break down this data any further, hence we can't know for sure how much of this is CDS. However, estimates were that at the peak, CDSs totaled globally $\$ 60$ to $\$ 70$ trillion, or perhaps io per cent of total derivatives.

Figure Io.I: Citi: Notional amount of credit derivatives (in \% of total assets)

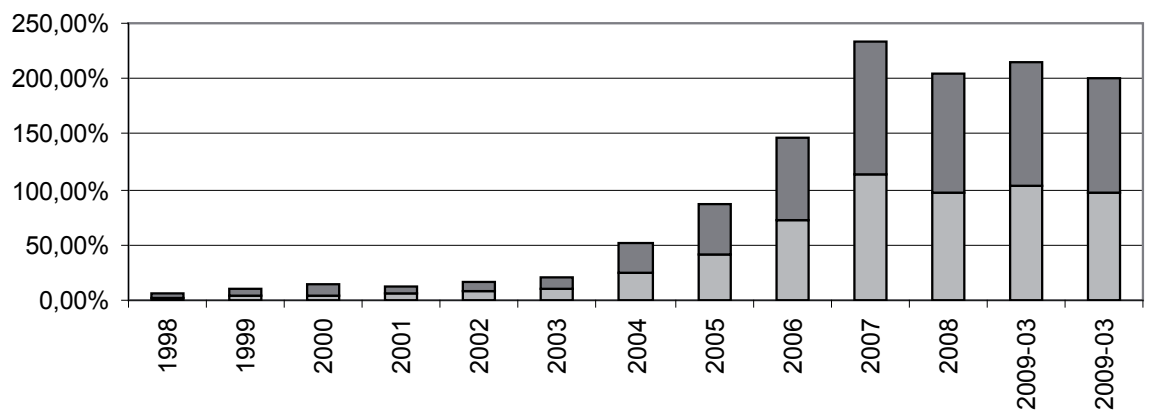

$\square$ Bank is guarantor $\square$ Bank is beneficiary

Source: Federal Deposit Insurance Corporation, SDI database

This is important since small losses on derivative holdings can wipe out bank capital. Derivatives are not counted in capital ratios. They allow banks to hedge risks, but also to take on risks by betting with derivatives. This allows them to increase leverage tremendously. We found out just how important this was when AIG failed. It used bailout funds to pay off bad bets made by Wall Street banks, including Goldman, on CDOs. In addition, there were ap- 
parently \$Io billion in bad debts which AIG has so far refused to cover. These appear to be pure gambling by its (bank) counterparties. That is, the banks placed bets on securities they did not hold. At the time of writing this paper, the information is still secret as the Federal Reserve Bank of New York (which handled the bailout of AIG) refuses to release the details.

Figure 10.2: Chase: Notional amount of credit derivatives (in \% of total assets)

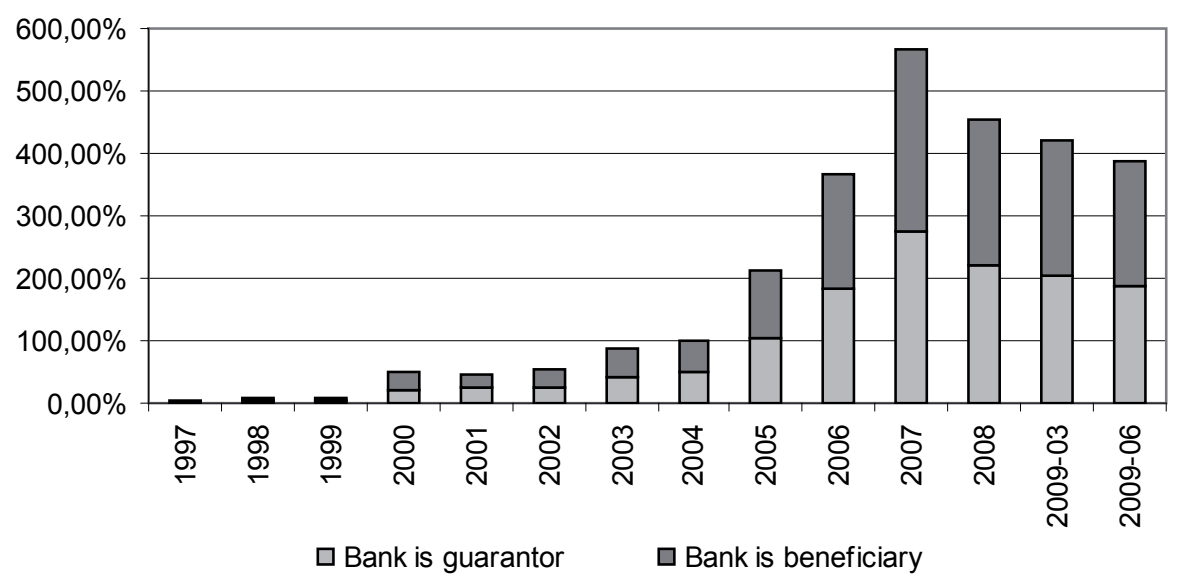

Source: Federal Deposit Insurance Corporation, SDI database

Figure 10.3: BOA: Notional amount of credit derivatives (in \% of total assets)

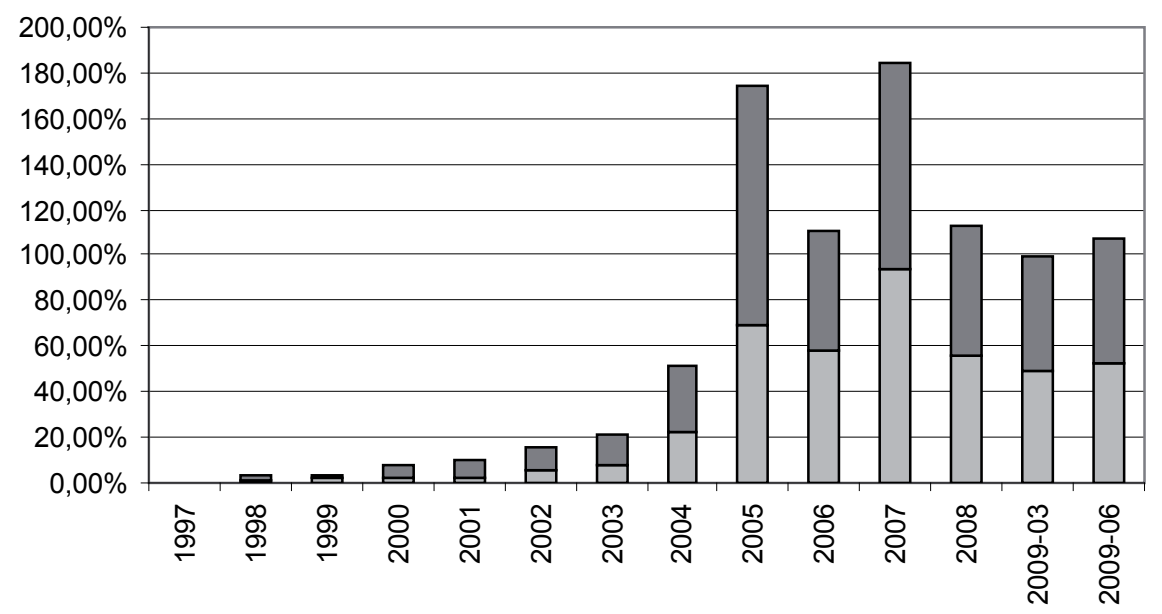

$\square$ Bank is guarantor $\square$ Bank is beneficiary

Source: Federal Deposit Insurance Corporation, SDI database 
Figure 10.4: Goldman Sachs: Notional amount of credit derivatives (in \% of total assets)

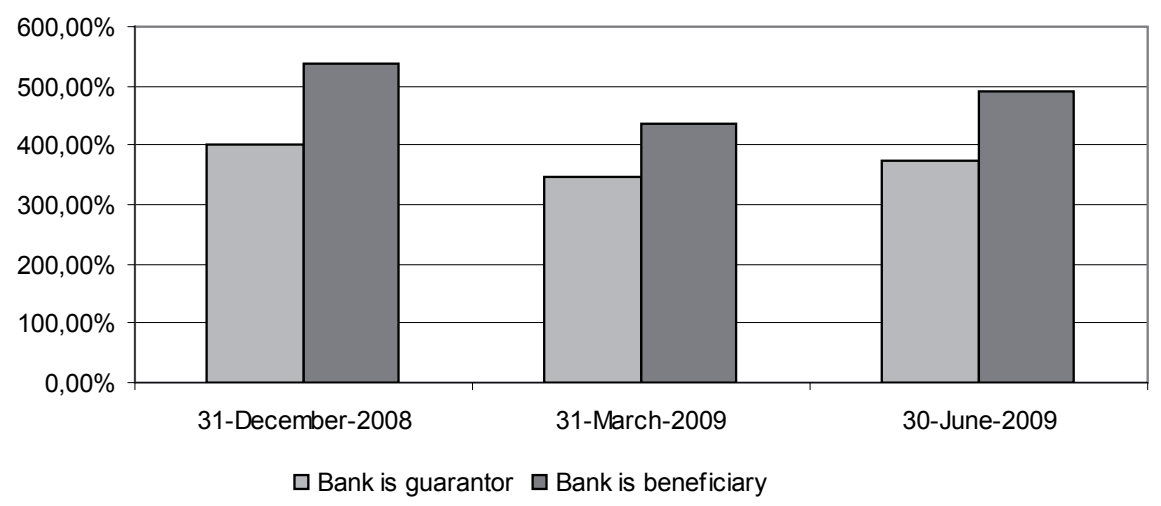

Source: Federal Deposit Insurance Corporation, SDI database

\section{Disparate effects of the crisis on financial institutions}

There has been a major redistribution of wealth and power in the financial sector as a result of the crisis. Wall Street as a whole shrank but not all companies have been affected equally by the crisis as shown in Table 3. The market capitalization of Citigroup, for example, has shrunk 62 per cent since the peak of the market and it could shrink more since it is still on government support. Bank of America's market value has decreased by 45 per cent since the peak. It has however, become bigger, in terms of asset size, by acquiring Merrill Lynch. JPMorgan Chase has been the largest beneficiary of the crisis, surpassing Citigroup and Bank of America as it became the largest bank in the US. Its value has decreased from the peak of the market but only by about 6 per cent, a small decline compared to its pears. To some extent it appears that this result is due to the more cautious approach that Morgan took to the new types of assets. Wells Fargo became the fourth largest bank in the US, in terms of assets, after acquiring Wachovia. It has grown over I2 per cent from the peak of the market. And note that peak was also the peak of the bubble.

So far, government has actually favored consolidation when faced with a failing financial institution. By creating mega-institutions, government's bail-out has given them immunity for future crises by labeling them 'too big to fail and ssystemically important ( while it refuses to provide a list naming its favored institutions, the list certainly includes the top 20). Determining which institutions will be bailed out and which will go under, government has conducted a major redistribution of wealth and power that could have far reaching implications for the future. 


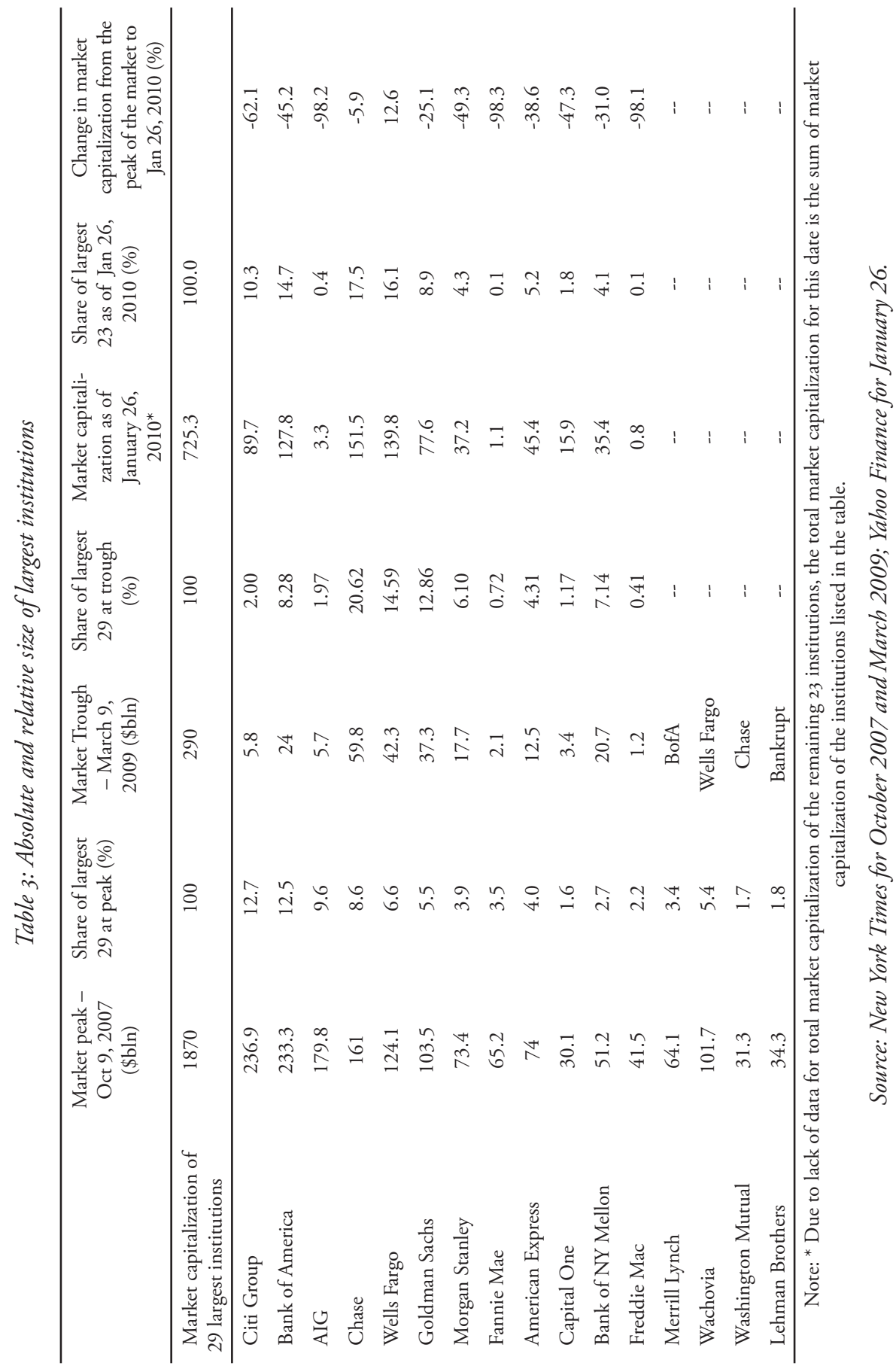




\section{Policy response}

Unlike many analyses of this crisis, including some that refer to Minsky's work, our thesis is that this is a systemic crisis that cannot be resolved by ramping up regulations, or prohibiting the most dangerous practices. We see the current situation as somewhat analogous to that of the early I930s - a crisis of financial capitalism. In the aftermath of that earlier crisis, a new form of capitalism was created - what Minsky called managerial welfare-state capitalism or what Galbraith called the new industrial state. What we are arguing is that a similar major transformation is required - a new New Deal. Thus, while we agree with many commentators that the seeds of this current crisis can be found in deregulation, risky financial innovations, fraud perpetrated by `bad apples`, and so on, we do not believe these analyses go far enough in recognizing the systemic nature of the crisis. Indeed, the deregulation itself was sendogenous , to some extent required by the evolution of the system, competition from shadow banks, and so on. That is, the crisis was an endogenously created result of the postwar form of capitalism that can only be rectified by measures re-directing the evolution of the system.

Our brief analysis of the mainstream policy proposals allows us to conclude that none of them will be effective in making the financial system safer. A detailed analysis of those proposals as well as our solutions proposed here can be found in Auerback/Wray (2009), Nersisyan/Wray (2010), and Tymoigne/Wray (2009). We understand that the proposals presented below may sound too radical or politically unfeasible. But the New Deal reforms didn't pass with ease either and indeed the financial reforms were phased in over years. The current crisis was perhaps not painful enough to create the necessary political conditions for a meaningful reform. We fear that there will be another even deeper crisis not far in the future which will make our currently too radical policy proposals politically feasible.

When the bubble burst and a global crisis was created, it seemed that there was a general consensus for meaningful reform. It was obvious that deregulation, de-supervision, and self-regulation had failed and that real change was necessary to prevent the system from destroying itself. Additionally, reform was virtually required to attenuate public anger over the bailouts. In the eyes of many, the economy has survived the worst and is on a path to a recovery. Many economists now argue that it is time for the government to work out an exit strategy to downsize its share in the financial sector. Those fearing inflation have also argued that the Fed will soon need to start raising interest rates. Many on Wall Street, who were very eager to receive government support when their institutions were failing, are now arguing that government intrusions are unacceptable. In fact, despite major injections of bailout funds, the government has actually played a negligible role in the decision making of those firms it helped. One year after President Obama took over the government hasn't made any significant progress in reforming Wall Street.

There have been few criminal prosecutions of the financial geniuses who engineered the crisis. Executive pay is still at all-time highs with Goldman Sachs' 30,000 employees expected to get as much as $\$ 700,000$ each in bonuses (Berenson 2009). On top of everything else, large banks still reap government subsidies: the Washington Post reports that banks with more than $\$$ IOo billion in assets are getting a competitive advantage by being able to borrow at in- 
terest rates 0.34 per centage points lower than rates charged to the rest of the industry (that advantage was only 0.08 per cent in 2007) (Cho 2009). Banks have been making record profits with Goldman Sachs, Merrill Lynch, Morgan Stanley and the investment banking division of JPMorgan Chase reporting \$22.5 billion in earnings in the first nine months of 2009 .

So we do realize that many point to reported profits of the megabanks as evidence that the policies have worked, although we are very skeptical of the claim that the crisis is over. Above we have argued that these policies have promoted consolidation and concentration. Further, they have permitted banks to continue to do what they were doing - that is, to engage in risky practices. It is not possible to say with certainty how banks have been able to manufacture profits even though they are not making loans, and even though they still hold billions of bad, delinquent loans. The reported profits come from trading activity. It is relatively easy to manufacture profits on trades of opaque assets that do not have real market prices - indeed, that is exactly what led to the crisis. We suspect that most of the reported profits result from `quid pro quo trades - you buy my bad assets at inflated prices, I buy yours, and we both book big profits. That is exactly what US thrifts did in the I980s. In any event, the financial sector is again capturing an outsized share of corporate profits - which we believe is not a good sign even if the profits are real - as shown in Figure II. In recent quarters the financial sector has rallied (note: profits relative to GDP are indexed to Ioo in the first quarter of 200I). At the peak of the bubble, the financial sector's profits relative to GDP had increased by 50 per cent. In the crash, the financial sector's share fell to less than half of its 200 I value. However, it has already recovered to its 200 I share. The non-financial sector's profit share also rose in the boom, but did not fall nearly so low in the crash - and its recovery has been far less robust.)

Figure II: Profits of different sectors as \% of GDP (indexed to QI 200I)

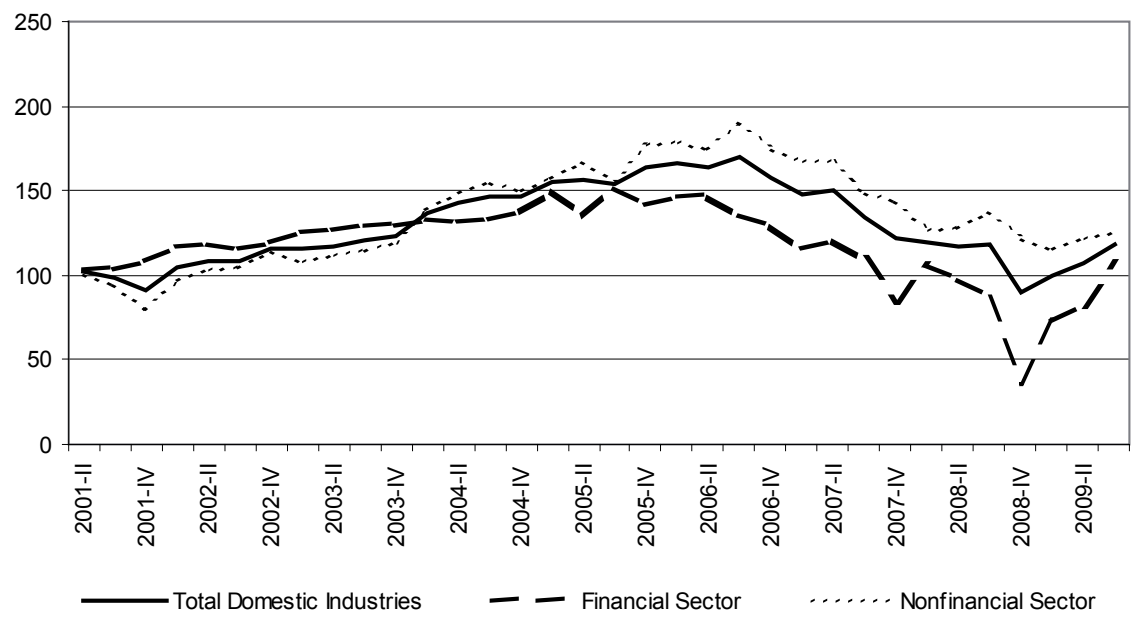


We are also doubtful that the US economy is really recovering. First, GDP got a big boost from the scash for clunkers p program in which the US government offered a subsidy for new car purchases on the condition that older cars were crushed. Table 4 shows the boost this added to third quarter 2009 GDP growth: I.45 per cent while total GDP growth was 2.2 per cent. More recently, most economic growth has resulted from inventory investment as business refilled shelves. The 5.7 per cent GDP growth for the fourth quarter of 2009 came from 3.39 per cent growth in inventories and only 2.34 per cent growth in final sales of domestic product. Since the stimulus package will have run out by summer 20Io, and since no large fiscal package is likely to be forthcoming, we doubt that a true recovery will get underway. Finally, when we look at the global deflationary pressures that exist - with the lone exception of the BRICs (Brazil, India and China) - we do not see where the impetus for growth will come from.

Table 4: Contributions to per cent change in real gross domestic product by major type of product (seasonally adjusted at annual rates)

\begin{tabular}{l|cc}
\hline Gross domestic product & 2009-III & 2009-IV \\
\hline Total GDP Growth & 2.2 & 5.7 \\
Final sales of domestic product & 1.54 & 2.34 \\
Durable Goods & 0.76 & -0.01 \\
Non-Durable Goods & 0.15 & 1.71 \\
Services & 0.7 & 1.14 \\
Structures & -0.06 & -0.5 \\
Change in private inventories & 0.69 & 3.39 \\
Durable Goods & 0.88 & 2.07 \\
Non-Durable Goods & -0.19 & 1.32 \\
Addenda: & & 0.61 \\
Motor vehicle output & 1.45 & \\
\hline
\end{tabular}

Source: $B E A$

Obama warned Wall Street that this is going to be "the most ambitious overhaul of the financial system since the Great Depression «, but he is not going to impose real change:

"Instead, we are calling on the financial industry to join us in a constructive effort to update the rules and regulatory structure to meet the challenges of this new century [...]. We have sought ideas and input from industry leaders, policy experts, academics, consumer advocates, and the broader public«. (Obama 2009)

The government is looking at Wall Street with naïveté, hoping it will reform itself. However, if something can be learnt from the crisis it is that we cannot rely on these institutions 
to self-regulate. Geithner's proposed legislation seeks to give the government the ability to take over failing giant institutions and to resolve them in an orderly manner to prevent ripple effects throughout the system. This proposal is not only not bold enough but is also redundant as the government already has the power to take over and resolve large institutions like it did in case of the Continental Illinois bank (Johnson 2009). Hence, the regulatory reform proposal of the administration is timid and appears to be aimed at saving the system as it is, without any major changes. But even a conservative proposal like this is highly unlikely to make it far considering the strong resistance from the financial sector and its track record of effectively blocking any change it doesn't like.

A progressive policy aimed at solving the issue of too big to fail institutions would break down every institution that is considered to be ssystemically important ' into smaller functional pieces. Too big to fail institutions shouldn't be allowed to exist. They are too complex and too big to be safely managed and resolved if necessary. Allowing such institutions to exist gives too much power, both market and political, to behemoths. Instead, the FDIC should be required to determine which large banks are insolvent based on current market values. The balance sheets of the top 20 banks should be examined on a consolidated basis, with derivative positions netted (data indicates that most derivatives are held by the biggest banks, which serve as counterparties for one another). After netting positions the insolvent banks would be resolved following two principles: resolution at the least cost to the FDIC and with a view to downsizing institutions. The ultimate objective must be to minimize impacts on the rest of the banking system. It will be necessary to cover some uninsured losses to other financial institutions (smaller commercial banks that are otherwise solvent) as well as to equity holders (such as pension funds) arising due to the resolution (Auerback/Wray 2009).

Close regulation of securitized products and establishing a centralized clearinghouse for derivative trades is the second major component of the plan. Originators of securitized products would have to keep some portion of those assets on their books. However, a large part of the disturbances of the early 2008 were due to Bear Stearns, Lehman Brothers, and others doing exactly that (Johnson 2009). This and other types of recursive arrangements were the main reason why many institutions went insolvent and were near the brink of failure. This proposal is actually rather conservative considering the role that mortgage backed securities played in the debacle of the financial system. Even today many supporters of securitization defend it as a good tool for distributing risks to those who are most willing to bear it. But we have learnt during this crisis that those who are most willing to bear the risk might not always be able to do so. Moreover, distributing risk doesn't eliminate it from the system - indeed it increases it by removing the incentive to underwrite. Without going further into detail on the flaws of securitization which have been extensively examined, we argue that securitization should be forbidden altogether as an activity that regulated and protected banks would be permitted to undertake. By separating risk from responsibility, it creates perverse incentives and helps generate bubbles which will inevitably burst. Auerback argues that banks should be required to keep loans on their balance sheets as there is 
no public purpose served by selling loans to third parties. And as we have seen there can be substantial negative consequences (Auerback 2009).

Many critics have proposed legislation to deal with the issue of credit default swaps, a major factor behind magnifying the effects of the crisis. For example, a popular proposal is to create a regulated exchange for Credit Default Swaps and other financial derivatives through which banks and other financial institutions will be required to trade these instruments. That would make the market more transparent, and could reduce counterparty risk. But even this very conservative policy has received strong resistance from the financial sector and going into the third year of the crisis, the derivatives market is still largely unregulated. The financial lobby is actively working to water down any regulatory tightening on derivatives, a major source of profits and hence bonuses for the banks.

We think that it would be best to simply forbid regulated and protected banks from using credit default swaps - they should bear the risks so that they have an incentive to do proper underwriting. Hence we agree with analysts who have rightly argued that banks should be forbidden to buy or sell credit default insurance as they don't serve any public purpose. These are merely a vehicle for the financial sector for redistributing wealth and reaping massive profits. CDS allow the lender to be paid off even when the borrower defaults on their asset thus making the bank indifferent to the creditworthiness of the borrower. The solution to the CDS problem is to make big banks net out gross CDS positions among themselves and then forbid their use of Credit Default Swaps altogether. (Auerback/ Wray 2009, Tymoigne/Wray 2009)

Perhaps the best part of the proposal put forward by Washington, and the one least likely to pass is the creation of a new Consumer Finance Protection Agency which would protect consumers from deceptive practices and abuse. It would have the powers to regulate mortgages, credit cards and any other form of consumer debt. As NY-Times reports, however, big financial institutions have unified with smaller community banks to fight against the creation of this agency (Labaton/Zeleny 2009). We realize that the Fed would like to take over control of this function, but it has demonstrated over the past several decades that it is particularly ill-suited to protect consumers. It is captured by its owners - the member commercial banks.

Most recently, under the pressure of public anger, Obama proposed a new $>$ Volcker Ruler that would prohibit regulated and publicly insured financial institutions from operating hedge funds, private equity funds, or engaging in proprietary trading. The expectation is that by somewhat limiting the types of activities these institutions can be engaged in, their further consolidation will be prevented and they will even shrink. This is a step in the right direction but is not nearly enough to make the financial sector safe. Any institution that has access to the Fed and to the FDIC should be prohibited from making any kinds of trades. They should return to their traditional roles of making loans, purchasing securities, and then holding them through maturity. Any bank that is unhappy with these new conditions can hand back its bank charter and become an unprotected financial institution. Those that retain their charters will be treated as public-private partnerships, which is what banks are. They put up \$5 of their own money, then gamble with $\$ 95$ of government 
(guaranteed) money. The only public purpose they serve is underwriting - and that only works if they hold all the risks.

And finally, the solution to the current mess should not bypass the issue of fraud. It is rampant in the financial sector and has certainly increased since the crisis (Where do you think all of those record profits come from?). Fraudulent institutions must be shut down, investigated and their management jailed (Black 2009 and various Congress testimonies and posts on NEP).

It is obvious that the bailout policies haven't worked to fix the economy. Trying to save the system as it is and even exacerbating the already existing problems along the way create the necessary conditions for another massive financial crisis and even a depression to occur in the not so remote future. Bank balance sheets haven't been simplified, financial institutions haven't been restructured and concentration problems haven't been resolved. The only changes that have taken place have been superficial and have contributed to making the system even more fragile. Debts are still at historically high levels. The large four banks have derivatives on their balance sheets which are thousands of times more than their assets. The fundamental causes of the crisis haven't been addressed; the system today is in a worse shape than it was prior to the crisis. The reforms proposed by the government will not prevent any future crises and they wouldn't have prevented this one if they were in place.

The more progressive policies proposed above would help simplify the financial system, reduce concentration, and decrease its size relative to the economy, something that the administration's proposal will fail to achieve. We will also need debt relief for households. This can include a package of policies that would replace unaffordable mortgages with better terms provided by strengthened GSEs. Some underwater mortgages should be foreclosed, with homeowners converted to renters with an option to repurchase the home later. Tax relief and job creation will help to boost ability to service debt, and will help to jumpstart the economy so that firms can stop downsizing. The public retirement system will need strengthening and real health care reform is required (Nersisyan/Wray 20IO, Auerback/Wray 20I0).

The role of managed money must be reduced; this can be encouraged by eliminating various subsidies including tax-advantaged saving. In the place of private pensions we need to expand and strengthen publicly provided pensions. Of course, all of this is a movement in the opposite direction to that currently envisioned by the Obama administration - which is actually trying to increase the financialization of health care by forcing all individuals to purchase health insurancer. And managed money is looking to financialize death (through securitization of `death settlements`, buying up life insurance policies of people with terminal illnesses) (Auerback/Wray 2009). Managed money is searching for its next bubble which is probably in commodities futures (again) or carbon futures trading. Unless it is constrained, another boom and bust is inevitable.

Minsky argued that depressions play a useful role for capitalist economies: they simplify balance sheets by wiping out financial assets and liabilities. The result is a system where hedge units are a majority and which therefore is relatively stable. One reason why financial fragility has built up over time in the post-war period was because there were no depres- 
sions. To be sure, there were financial crises that wiped out a significant proportion of debt in the economy. But as Big Government and Big Bank set floors and ceilings in the economy, each time the system recovered with still high levels of debt. But the experience shows that this is not sustainable. While we are not advocating that the government allow a I930s style debt deflation, we argue that for any policy to be effective in the longer run, it needs to involve balance sheet simplification but without depression.

The government has all the powers necessary to re-regulate Wall Street. New Deal reforms were very successful in containing instability for a couple of decades. But innovations as well as deregulation rendered these ineffective. Minsky argued that the Fed and legislation can guide the evolution of the financial system to constrain instability by encouraging institutions and practices that reduce instability and constraining those that enhance it. $\mathrm{He}$ also argued that if the Fed can intervene to put a floor on the collapse it must also "take initiatives to prevent the development of practices conductive to financial instability (Minsky 1986/2008: 349). The current crisis was a warning sign. The question is: will we take this warning seriously and reform the system or do we need another Great Depression to finally bring about real change?

"The profit-seeking bankers almost always win their game with the authorities, but, in winning, the banking community destabilizes the economy; the true losers are those who are hurt by unemployment and inflation.« (Minsky 1986/2008: 279)

As long as there are large pools of managed money looking for high returns, the question is where the next bubble will develop. The only hope is a substantial downsizing of managed money, which will help to reduce the influence of money managers on our economy and our political system.

\section{References}

Auerback, M., Wray, L.R. (2010): Toward true health care reform: More care, less insurance, Public Policy Brief No. IIo, Levy Economics Institute, March 20 Io.

Auerback, M., Wray, L.R. (2009): Banks running wild: The subversion of insurance by, Life Settlements and Credit Default Swaps, Policy Note, Levy Economics Institute, 2009/9.

Auerback, M. (2009): Obama’s finance reform speech fizzles; big banks set to reinflate bubble, posted on New Deal 2.0 Website, September I6, 2009, URL: http://www.newdeal20. org/2009/o9/r6/obamas-finance-reform-speech-fizzles-big-banks-set-to-reinflatebubble-4726/.

Berenson, A. (2009): A year after a cataclysm, little change on Wall St., in: The New York Times, September I2, 2009.

Black, W. (2009): Systematically dangerous institutions, New Economic Perspectives Blog, October I5, 2009, URL: http://neweconomicperspectives.blogspot.com/2009/Io/ systemically-dangerous-institutions.html.

Cho, D. (2009): , Too big to fail have grown even bigger: Behemoths born of the bailout reduce consumer choice, tempt corporate moral hazard, in: Washington Post, August 28, 2009. 
Flow of Funds (2009): Accounts of the United States, 1945-2008, June II, 2009.

Guide to Flow of Funds Accounts, Volume 2.

Johnson, S. (2009): The defanging of Obama's regulation plan, in: The New York Times, June I8, 2009.

Krippner, G. (2005): The financialization of the American economy, in: Socio-Economic Review, 3(2), I73-208.

Labaton, S., Zeleny, J. (2009): For Obama, a chance to reform the Street is fading, in: The New York Times, September 15, 2009.

Lewis, M. (2009): The man who crashed the world, in: The Vanity Fair, August.

Minsky, H.P. (1986/2008): Stabilizing an Unstable Economy, New York: McGraw Hill.

Mishkin, F. (2007): The Economics of Money, Banking and Financial Markets, $8^{\text {th }}$ ed., Boston: Pearson Education.

Nersisyan, Y., Wray, L.R. (20I0): The trouble with the pensions: Toward an alternative public policy to support retirement, Public Policy Brief No. I09, Levy Economics Institute, March 2010.

Obama, B. (2009): Normalcy cannot lead to complacency, Speech delivered in New York, September I4, 2009, available at URL: http://www.whitehouse.gov/blog/NormalcyCannot-Lead-to-Complacency.

Tymoigne, E., Wray, L.R. (2009): It isn't working: Time for more radical policies, Public Policy Brief No. I05A, Levy Economics Institute, October 2010.

Wray, R.L. (2009): The rise and fall of money manager capitalism: A Minskian approach, in: Cambridge Journal of Economics, 33, $807-828$. 